\title{
Randomized study between thymoglobulin and posttransplant cyclophosphamide in patients with chronic myeloid neoplasms undergoing unrelated allogeneic stem cell transplantation
}

\begin{abstract}
Elena V. Morozova, Ivan S. Moiseev, Yulia Yu. Vlasova, Nikolay Yu. Tcvetkov, Yulia V. Rudnitskaya, Maria V. Barabanschikova, Anna G. Smirnova, Elena I. Darskaya, Sergey N. Bondarenko, Boris V. Afanasyev

Raisa Gorbacheva Memorial Research Institute of Pediatric Oncology, Hematology and Transplantation, Pavlov University, St. Petersburg, Russia
\end{abstract}

Dr. Elena V. Morozova, PhD, Raisa Gorbacheva Memorial Research Institute of Pediatric Oncology, Hematology and Transplantation, Pavlov University, L. Tolstoy St. 6-8, 197022, St. Petersburg, Russia
Phone: +7 (911) 9278229

E-mail: dr_morozova@mail.ru

Citation: Morozova EV, Moiseev IS, Vlasova YY et al. Randomized study between thymoglobulin and posttransplant cyclophosphamide in patients with chronic myeloid neoplasms undergoing unrelated allogeneic stem cell transplantation. Cell Ther Transplant 2020; 9(1): 53-59.

\section{Summary}

Despite growing evidence on the use of posttransplantation cyclophosphamide (PTCY) in matched unrelated transplantation in acute leukemia patients, prospective evidence to support this type of prophylaxis in myelodysplastic syndrome (MDS), chronic myeloproliferative neoplasms and chronic myeloid leukemia (CML) patients is lacking. In this patient population we conducted a prospective randomized study of PTCY $v s$ thymoglobulin for graft-versus-host disease (GvHD) prophylaxis in the setting of 10/10 HLA-matched unrelated transplantation (NCT02627573, clinicaltrials.gov). The strata for randomization was pretransplant assessment of mortality score. The study was terminated prematurely due to poor recruitment, but 33 patients were enrolled, 17 in the PTCY and 16 in the thymoglobulin group. Median follow up was 29 months. There was no difference between groups in the incidence primary graft failure ( $12.50 \%$ vs $11.8 \%, \mathrm{p}=0.9)$, acute GvHD grade II-IV (23\% vs $6 \%, \mathrm{p}=0.2)$, moderate and severe chronic GvHD $(25 \%$ vs $23 \%, \mathrm{p}=0.4)$ in the thymoglobulin and PTCY arms, respectively. However there was a significantly higher overall survival ( $82 \%$ vs $30 \%, \mathrm{p}=0.0126)$, event-free survival $(61 \%$ vs 26\%, $\mathrm{p}=0.0335)$, and GvHD-relapse free survival ( $61 \%$ vs $16 \%, \mathrm{p}=0.0072)$ in the PTCY group due to reduced late infection-related mortality. No differences was observed in terms of toxicity. In conclusion, despite incomplete recruitment, the study created the basis for the use of PTCY in unrelated transplantations from fully matched unrelated donors in CML and MDS. Future studies are required to confirm if there is a benefit of PTCY-based prophylaxis over thymoglobulin.

\section{Keywords}

Posttransplant cyclophosphamide, myelodysplastic syndrome, chronic myeloid leukemia, chronic myeloproliferative neoplasm, matched unrelated donor. 


\section{Introduction}

Myelodysplastic syndrome (MDS), chronic myeloproliferative neoplasms (MPN) and chronic myeloid leukemia (CML) comprise about $15 \%$ of patients with indication for allogeneic stem cell transplantation (SCT) [1]. Nonetheless SCT in this group of patients is associated with significant non-relapse mortality reaching $26 \%$ in advanced chronic myeloid leukemia [2], 32\% in myelodysplastic syndrome [3] and $25-36 \%$ in various types of MPN $[4,5]$. The main reasons of mortality in these diseases are infectious complications, graft-versus-host disease and primary graft failure which is significantly more frequent than in other hematological malignancies [6].

Posttransplant cyclophosphamide (PTCY) is an approach which is gaining popularity for haploidentical (Haplo) and mismatched unrelated donor (MUD) transplantation. This approach in the large retrospective study demonstrated reduced incidence of GvHD, reduced non-relapse mortality and improved GvHD-relapse-free survival (GFRS) compared to in vivo T-cell depletion methods both in Haplo and MUD settings [7,8]. But most of the supportive data describes acute leukemia patients [9] or MDS/ MPN patients are combined in the analysis with acute leukemia [10]. Thus there is limited data whether PTCY in the group of chronic myeloid neoplasms provide the same benefit as in acute leukemias. Also there was a concern that in the setting of MDS/ CML/MPN PTCy might increase the primary graft failure incidence.

The majority of SCTs in MDS and CML patients are unrelated, because of older age and comorbidities of the related donors and better outcomes after transplantation from a young donor [11]. So we conducted a single-center prospective randomized study in unrelated SCT recipients between the standard approach of GvHD prophylaxis with thymoglobulin and PTCY. The other components of GvHD prophylaxis was the same as well as the conditioning and supportive care.

\section{Patients and methods}

\section{General parameters of the patients and transplants}

The prospective single-center randomized study was conducted in the First Pavlov Medical university. The study was approved by the local Ethical committee and was conducted according to the good clinical practices and Helsinki declaration. All patients signed informed consent to participate in the study and processing of the personal data. The study was registered at clinicaltrials.gov, NCT02627573. The conclusion criteria were the diagnosis of chronic myeloid leukemia or myelodysplastic Syndrome or myeloprolipherative neoplasm unclassified or atypical chronic myelogenous leukemia with indications for SCT and presence of 10/10 HLAmatched unrelated donor. The donor and recipient must be identical by the following genetic loci: HLA-A, HLA-B, HLA-Cw, HLA-DRB1, and HLA-DQB1. Mismatches in these loci were not allowed. Also only patients were included in whom the donor agreed to donate peripheral blood stem cells (PBSC). The exclusion criteria were the presence of severe concurrent illness, prior history of anaphylaxis to thymoglobulin, moderate or severe cardiac dysfunction, left ventricular ejection fraction $<50 \%$, moderate or severe decrease in pulmonary function, FEV $1<70 \%$ or DLCO $<70 \%$ of predicted, respiratory distress at least grade I, severe organ dysfunction: AST or ALT $>5$ upper normal limits, bilirubin $>1.5$ upper normal limits, creatinine $>2$ upper normal limits, creatinine clearance $<60 \mathrm{~mL} / \mathrm{min}$., uncontrolled bacterial or fungal infection at the time of enrollment, requirement for vasopressor support at the time of enrollment, Karnofsky index $<30 \%$, pregnancy, and somatic or psychiatric disorder making the patient unable to sign informed consent. The study during 2015-2019 has enrolled 33 patients: 16 in the thymoglobulin arm and 17 in the PTCY arm. The study was terminated prematurely due to poor recruitment. All recruited patients were included in the analysis. The study group was well balanced with no significant differences in characteristics of patients (Table 1).

\section{Study procedures}

All patients received conditioning with fludarabine $180 \mathrm{mg} / \mathrm{m}^{2}$ over 6 days and oral busulfan $10 \mathrm{mg} / \mathrm{kg}$ over 3 days. Patients in the thymoglobulin group received GvHD prophylaxis with thymoglobulin $2.5 \mathrm{mg} / \mathrm{kg}$ on days -3 and -2 , tacrolimus $0.03 \mathrm{mg} / \mathrm{kg} /$ day starting day -1 with target concentration 5-15 ng/ml and mycophenolate mofetil (MMF) $30 \mathrm{mg} / \mathrm{kg} /$ day starting. The MMF was continued until day +30 . Tacrolimus was continued until day +100 and gradually tapered over 1 month in absence of GvHD. Steroids were used in this group as the pre-medication to thymoglobulin and graft infusion. In the PTCy group patients received cyclophosphamide $50 \mathrm{mg} / \mathrm{kg}$ on days +3 and +4 . Mesna 50 $\mathrm{mg} / \mathrm{kg}$ was administered as 24-hour infusion on the days of cyclophosphamide administration. MMF $30 \mathrm{mg} / \mathrm{kg} /$ day was started on day +5 and continued until day +35 . Tacrolimus $0.03 \mathrm{mg} / \mathrm{kg} /$ day was started on day +5 with target concentration 5-15 ng/ml. Tacrolimus in this arm was in the same way continued until day +100 and gradually tapered over 1 month in absence of GvHD. Use of steroids was prohibited from day -5 to day +5 . The rest of the supportive care was the same in both arms. The standard antifungal prophylaxis was fluconazole starting on day 0 and continued until engraftment.

\section{Clinical outcomes}

Time to disease relapse, acute GvHD (GvHD), moderate to severe chronic GvHD (cGvHD), non-relapse mortality (NRM), overall survival (OS), event-free survival (EFS), and GvHD-relapse free survival (GRFS) were defined as the time from transplantation to the event. Incidence of aGvHD was calculated at 125 days after HSCT, and the time frame for the other outcomes was free years. Events for EFS were relapse or death. Events for GRFS were either death, relapse, grades III-IV acute GvHD or systemic therapy-requiring chronic GvHD [12]. Patients were censored at the time of last contact or a second transplantation for all outcomes. Disease relapse was defined as morphologic or cytogenetic evidence of disease with pre-transplantation characteristics. Disease staging, including bone marrow biopsies, was routinely performed on days $+30,+60,+100,+180,+365$ post-transplant. The Consensus Conference criteria and National Institutes 
CLINICAL STUDIES

Table 1. Characteristics of patients

\begin{tabular}{|c|c|c|c|}
\hline Parameter & Thymoglobulin (n=16) & PTCY (n=17) & P-value \\
\hline Age, median (range, years) & $45(18-60)$ & $46(26-57)$ & 0.38 \\
\hline Diagnosis, n & $\begin{array}{l}\text { CML } 4 \\
C P-3 \\
A P-1 \\
\text { MDS } 11 \\
A E B /-1 \\
A E B / I-8 \\
M L D-2 \\
\text { MPN unclassifiable } 1\end{array}$ & $\begin{array}{l}\text { CML } 8 \\
C P-1 \\
A P-1 \\
B C-2 \\
\text { MDS } 8 \\
A E B I-2 \\
A E B / I-6 \\
\text { MPN unclassifiable } 1\end{array}$ & 0.41 \\
\hline Male/female, n & $6 / 10$ & $10 / 7$ & 0.22 \\
\hline High cytogenetic risk & $53 \%$ & $17 \%$ & 0.11 \\
\hline Female donor & $31 \%$ & $29 \%$ & 0.90 \\
\hline AB0 mismatch, $n$ & $\begin{array}{l}\text { None } 6 \\
\text { Major } 4 \\
\text { Minor } 5 \\
\text { Mixed } 1\end{array}$ & $\begin{array}{l}\text { None } 7 \\
\text { Major } 4 \\
\text { Minor } 4 \\
\text { Mixed } 2\end{array}$ & 0.92 \\
\hline $\begin{array}{l}\text { CMV serostatus, } \\
\text { Donor/recipient, n }\end{array}$ & $\begin{array}{l}-/-2 \\
-/+7 \\
+/+7\end{array}$ & $\begin{array}{l}+/-2 \\
-/+8 \\
+/+7\end{array}$ & 0.25 \\
\hline
\end{tabular}

$\mathrm{CML}=$ chronic myeloid leukemia, $\mathrm{MDS}=$ myelodysplastic syndrome, $\mathrm{MPN}=$ myeloproliferative neoplasm, $\mathrm{CP}=$ chronic phase, $\mathrm{AP}=$ accele ration phase, $\mathrm{BC}$ = blast crisis, $\mathrm{AEB}$ - access blasts, $\mathrm{MLD}$ - multileaneage dysplasia.

of Health criteria were used for aGvHD and cGvHD grading $[13,14]$. Primary graft failure was defined as the complete absence of donor chimerism in bone marrow biopsy by day +40 . Time to engraftment was calculated as time from HSCT to unsupported neutrophil count $>500 / \mu$ l and white blood cell count $>1000 / \mu$ l for 3 consecutive days. Toxicity was assessed with CTCAE ver. 4.03. Sepsis and severe sepsis were diagnosed based on International Guidelines for Management of Severe Sepsis and Septic Shock [15]. Invasive mycosis was diagnosed in case of probable or proven infection according to EORTC/MSG guidelines [16]. The threshold for cytomegalovirus (CMV) reactivation was $>500$ copies $/ \mathrm{ml}$. Clinically significant CMV reactivation was defined as $>10000$ copies $/ \mathrm{mL}$. Veno-occlusive disease was diagnosed and graded based on EBMT criteria [17].

\section{Statistical evaluation}

The study primary endpoint was the incidence of primary graft failure. The study was planned to enroll 60 patients, 30 patients in each arm. With the study group size was calculated with $30 \%$ margin, 0.65 study power and 0.05 significance using Fisher's criterion. Secondary endpoints were incidence of acute grade II-IV acute GvHD, incidence moderate and severe chronic GvHD, non-relapse mortality, OS, EFS, GFRS, relapse incidence, toxicity and infectious complications. The strata for randomization was a pretransplant assessment of mortality (PAM) score [18]. The stratification was performed using Mann-Whitney U-criterion to achieve the minimal differences in PAM between the study groups.
The final median PAM values were 14.1 (range 7.8-25.2) and 14.1 (6.9-21.9) in the thymoglobulin and PTCY groups, respectively $(\mathrm{p}=0.98)$.

Comparison of patient characteristics was performed by Mann-Whitney test. The survival distributions for OS, EFS, GRFS were calculated using Kaplan-Meier methodology. The comparisons were made using the log-rank test. Cumulative incidence analysis with competing risks for aGvHD, cGvHD, relapse incidence and NRM was performed using Gray test. Relapse and NRM were accounted as competing risks. Incidence and severity of complications was compared using Chi-square and Mann-Whitney test. Analyses were conducted in SAS 9.3 (SAS Institute, Inc.).

\section{Results}

Median follow up in the study was 29 months (range 7-48). There was no difference in the incidence of primary graft failure: $12.50 \%$ (95\%CI $2 \%-38 \%)$ in the thymoglobulin arm and $11.8 \%$ (95\%CI 1\%-36\%) in the PTCY arm, $\mathrm{p}=0.95$. Three out of four patients with primary graft failure died, one was salvaged with second transplantation. All patients without primary graft failure survived to the day of engraftment. Median time to neutrophil engraftment was longer in the PTCY group: 20 (16-33) vs 16 (11-30) days, $\mathrm{p}=0.0017$. Time to white blood cell engraftment was also significantly longer: 21 (16-33) vs 15 (11-30) days, $\mathrm{p}=0.0016$. No differences were observed in the time to platelet engraftment: median 12 $(8-40)$ vs 15 (11-45) days, $\mathrm{p}=0.1482$. 
Acute GvHD grade II-IV was documented in 3 (23\%) patients in the thymoglobulin group and $1(6 \%)$ patients in the PTCY group $(p=0.20)$. No cases of acute GvHD grade IIIIV were documented. Moderate and severe chronic GvHD was diagnosed in 3 (23\%) patient after thymoglobulin and 4 (25\%) patients after PTCY ( $\mathrm{p}=0.41)$. Median time to chronic GvHD was a little shorter after thymoglobulin (5.5 months) compared to PTCY (15 months), $\mathrm{p}=0.11$. One patient in thymoglobulin and 2 patients in the PTCY group had mild chronic GvHD.

Patients after PTCY prophylaxis had significantly better outcomes of transplantation. 4-year OS was $82 \%$ (95\%CI $55-94 \%)$ vs 30\% (95\%CI 6-59\%), $\mathrm{p}=0.0126$; EFS was $61 \%$ (95\%CI $31-81 \%)$ vs $26 \%$ (95\%CI 5-54\%), $\mathrm{p}=0.0335$, GFRS
$61 \%$ 95\%CI (31-81\%) vs 16\% (95\%CI 1-46\%), $\mathrm{p}=0.0072$ (Figure 1). There was a comparable incidence of relapse between the groups ( $25 \%$ vs $29 \%, \mathrm{p}=0.77$ ), but significantly reduced non-relapse mortality in the PTCY group (6\% vs $38 \%, \mathrm{p}=0.0264$ ), which was main cause of the differences in survival outcomes. Primary graft failure and infectious complications were the only causes of non-relapse mortality in the study groups.

No unexpected toxicity was observed during the study. There was no significant difference in the incidence of early complications (Table 2). No cases of neurotoxicity or veno-occlusive disease were documented during the study. The infusion reactions in the thymoglobulin group were allergic reactions and in the PTCY group - one case of cystalgia.
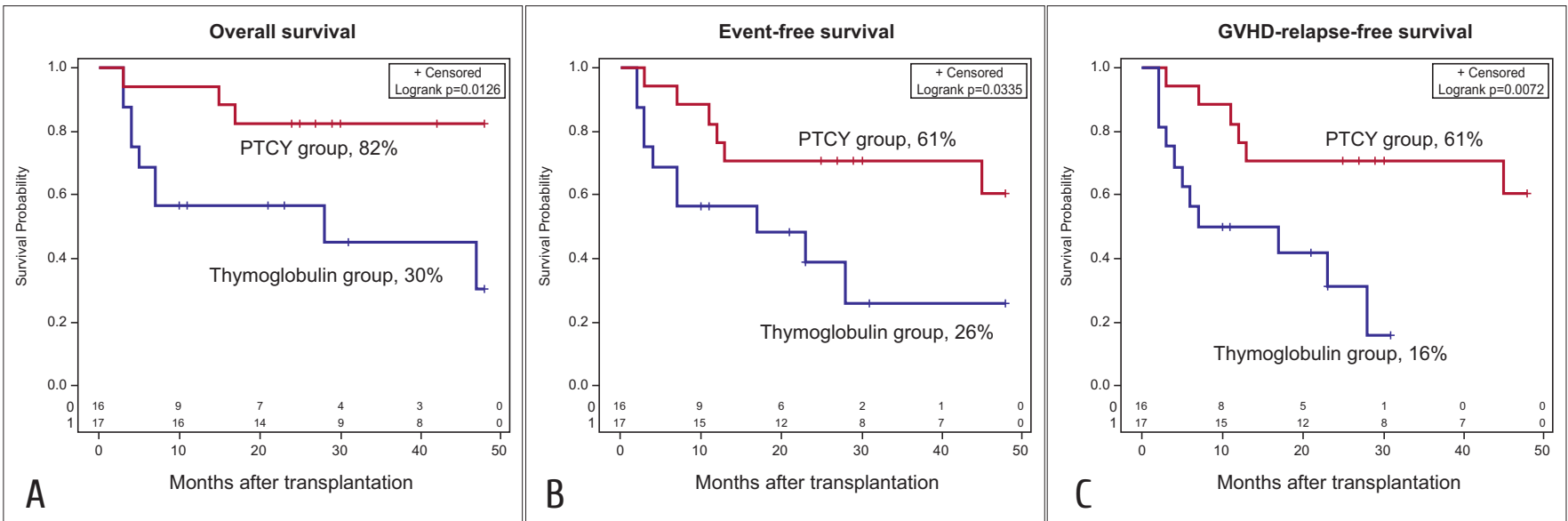

Figure 1. Overall (A), event-free (B) and GvHD-relapse-free (C) survival. The percentages shown are 4-year Kaplan-Mayer estimates

Table 2. Toxicity and complications observed in ATG and PTCY groups

\begin{tabular}{|l|l|l|l|}
\hline Parameter & Thymoglobulin (n=16) & PTCY (n=17) & P-value \\
\hline $\begin{array}{l}\text { Liver toxicity grade 2 } \\
\text { Liver toxicity grade 3 }\end{array}$ & $\begin{array}{l}1 \text { patient } \\
3 \text { patients }\end{array}$ & $\begin{array}{l}3 \text { patients } \\
0 \text { patients }\end{array}$ & 0.12 \\
\hline $\begin{array}{l}\text { Renal toxicity grade 1 } \\
\text { Renal toxicity grade 2 } \\
\text { Renal toxicity grade 3 }\end{array}$ & $\begin{array}{l}6 \text { patients } \\
1 \text { patient } \\
1 \text { patient } \\
1 \text { patients } \\
0 \text { patients }\end{array}$ & 0.78 \\
\hline TA-TMA & 0 patients & 1 patient & \\
\hline Mucositis grade 2 & 6 patients & 4 patients & 0.35 \\
\hline Mucositis grade 3 & 3 patients & 0.18 \\
\hline Hemorrhagic cystitis grade 2 & 1 patient & 2 patients & \\
\hline Preengraftment sepsis & 2 patients & 4 patients & 0.66 \\
\hline Preengraftment severe sepsis & 0 patients & 0.52 \\
\hline Invasive mycosis & 2 patients & 1 patient & 0.36 \\
\hline CMV reactivation & 7 patients & 8 patients & 0.43 \\
\hline Infusion reaction & 3 patients & 1 patient & 0.87 \\
\hline
\end{tabular}

Note: TA-TMA = transplant-associated microangiopathy. Infusion reaction is defined as any reaction during or immediately after infusion that required change in the systemic therapy. 


\section{Discussion}

The study was originally developed to demonstrate if there is a difference in primary graft failure after PTCY. Despite it was terminated prematurely due to poor recruitment, several approximations could be made. We have observed identical number of graft failures in the thymoglobulin and PTCY group. According to CIBMTR data the average number of primary graft failure is $5.5 \%$ and $\mathrm{CML}$ and MDS patients have the double risk. So the incidence in the current study was not only the same between groups, but almost identical to the one reported by large registry studies [6]. So it is likely that there is no impact of PTCY on the incidence of primary graft failure. On the other hand, we have not observed any positive impact of PTCY on engraftment in this patient population despite previous preclinical data [19]. Unlike primary graft failure engraftment of neutrophils is delayed by several days which in concordance with previously published data [7].

The study was not powered to capture the significance and survival and recruitment was not completed, but most striking results were obtained in terms of survival outcomes. PTCY prophylaxis was associated with significantly higher incidence of OS, EFS and GRFS. The differences were due to reduced non-relapse mortality, it was only $6 \%$ in the PTCY group. These extremely low incidence of NRM was recently confirmed in the retrospective [7] and prospective randomized [20] studies. Despite the situation in haploidentical transplantation where PTCY reduces mortality through more effective prevention of acute and chronic GvHD [8], here we observed identical incidence of both acute and chronic GvHD, but the difference was due to late severe bacterial infections. In this study $5 \mathrm{mg} / \mathrm{kg}$ dose of thymoglobulin was used which is reported to cause less profound immunosuppression and promote graft-versus-leukemia effect $[21,22]$. However the population of MDS and MPN patients is different from acute leukemia. There is a significant iron overload, which may increase the risk of infections after SCT and thymoglobulin effects might overlap with these negative impacts of iron overload [23]. Otherwise this might be an indication of better immunological recovery after unrelated transplantation with PTCY. Additional studies are required to confirm these assumptions.

\section{Conclusion}

Despite incomplete recruitment, this study provides some evidence on the use of PTCY-based prophylaxis for unrelated transplantations in patients with CML, MDS and MPN. The study has demonstrated that there is likely no impact of PTCY on the incidence of primary graft failure. Also it creates the basis for future studies to evaluate survival and immunological recovery in this patient population.

\section{Conflict of interest}

No conflict of interest reported.

\section{References}

1. Passweg JR, Baldomero H, Bader P, Basak GW, Bonini C, Duarte $\mathrm{R}$ et al. Is the use of unrelated donor transplantation leveling off in Europe? The 2016 European Society for Blood and Marrow Transplant activity survey report. Bone Marrow Transplant. 2018;53(9):1139-1148.

2. Radujkovic A, Dietrich S, Blok HJ, Nagler A, Ayuk F, Finke J et al. Allogeneic Stem Cell Transplantation for Blast Crisis Chronic Myeloid Leukemia in the Era of Tyrosine Kinase Inhibitors: A Retrospective Study by the EBMT Chronic Malignancies Working Party. Biol Blood Marrow Transplant. 2019;25(10):2008-2016.

3. Carré M, Porcher R, Finke J, Ehninger G, Koster L, Beelen $\mathrm{D}$ et al. Role of age and hematopoietic cell transplantation-specific comorbidity index in myelodysplastic patients undergoing an allotransplant. A retrospective study from the CMWP (Chronic Malignancies Working Party) of the EBMT. Biol Blood Marrow Transplant. 2019 Oct 21. pii: S1083-8791(19)30672-X. doi: 10.1016/j.bbmt.2019.10.015.

4. Onida F, de Wreede LC, van Biezen A, Eikema DJ, Byrne JL, Iori AP et al. Allogeneic stem cell transplantation in patients with atypical chronic myeloid leukaemia: a retrospective study from the Chronic Malignancies Working Party of the European Society for Blood and Marrow Transplantation. Br J Haematol. 2017;177(5):759-765.

5. Sharma P, Shinde SS, Damlaj M, Hefazi Rorghabeh M, Hashmi SK, Litzow MR et al. Allogeneic hematopoietic stem cell transplant in adult patients with myelodysplastic syndrome/myeloproliferative neoplasm (MDS/MPN) overlap syndromes. Leuk Lymphoma. 2017;58(4):872-881.

6. Olsson RF, Logan BR, Chaudhury S, Zhu X, Akpek G, Bolwell BJ et al. Primary graft failure after myeloablative allogeneic hematopoietic cell transplantation for hematologic malignancies. Leukemia. 2015;29(8):1754-62.

7. Battipaglia G, Labopin M, Kröger N, Vitek A, Afanasyev B, Hilgendorf I et al. Posttransplant cyclophosphamide vs antithymocyte globulin in HLA-mismatched unrelated donor transplantation. Blood. 2019;134(11):892-899.

8. Piemontese S, Ciceri F, Labopin M, Bacigalupo A, Huang $\mathrm{H}$, Santarone $\mathrm{S}$ et al. A survey on unmanipulated haploidentical hematopoietic stem cell transplantation in adults with acute leukemia. Leukemia. 2015;29(5):1069-75.

9. Brissot E, Labopin M, Ehninger G, Stelljes M, Brecht A, Ganser A et al. Haploidentical versus unrelated allogeneic stem cell transplantation for relapsed/refractory acute myeloid leukemia: a report on 1578 patients from the Acute Leukemia Working Party of the EBMT. Haematologica. 2019;104(3):524-532.

10. Shah MV, Saliba RM, Rondon G, Chen J, Soebbing D, Rus I et al. Pilot study using post-transplant cyclophosphamide (PTCy), tacrolimus and mycophenolate GvHD prophylaxis for older patients receiving 10/10 HLA-matched unrelated donor hematopoietic stem cell transplantation. Bone Marrow Transplant. 2019;54(4):601-606. 
11. Ayuk F, Beelen DW, Bornhäuser M, Stelljes M, Zabelina T, Finke J et al. Relative Impact of HLA Matching and NonHLA Donor Characteristics on Outcomes of Allogeneic Stem Cell Transplantation for Acute Myeloid Leukemia and Myelodysplastic Syndrome. Biol Blood Marrow Transplant. 2018;24(12):2558-2567.

12. Holtan SG, DeFor TE, Lazaryan A, Bejanyan N, Arora M, Brunstein CG et al. Composite end point of graft-versus-host disease-free, relapse-free survival after allogeneic hematopoietic cell transplantation. Blood. 2015;125(8):1333-1338.

13. Przepiorka D1, Weisdorf D, Martin P, Klingemann HG, Beatty P, Hows J, Thomas ED. 1994 Consensus Conference on Acute GvHD Grading. Bone Marrow Transplant. 1995; 15:825-828.

14. Filipovich AH, Weisdorf D, Pavletic S, Socie G, Wingard JR, Lee SJ et al. National Institutes of Health consensus development project on criteria for clinical trials in chronic graft-versus-host disease: I. Diagnosis and staging working group report. Biol Blood Marrow Transplant. 2005;11:945956.

15. Dellinger RP, Levy MM, Rhodes A, Annane D, Gerlach $\mathrm{H}$, Opal SM et al. Surviving Sepsis Campaign: international guidelines for management of severe sepsis and septic shock, 2012. Intensive Care Med. 2013;39(2):165-228.

16. De Pauw B, Walsh TJ, Donnelly JP, Stevens DA, Edwards JE, Calandra $\mathrm{T}$ et al. Revised definitions of invasive fungal disease from the European Organization for Research and Treatment of Cancer/Invasive Fungal Infections Cooperative Group and the National Institute of Allergy and Infectious Diseases Mycoses Study Group (EORTC/MSG) Consensus Group. Clin Infect Dis. 2008;46(12):1813-1821.

17. Mohty M, Malard F, Abecassis M, Aerts E, Alaskar AS, Aljurf $\mathrm{M}$ et al. Sinusoidal obstruction syndrome/veno-occlusive disease: current situation and perspectives - a position statement from the European Society for Blood and Marrow Transplantation (EBMT). Bone Marrow Transplant. 2015;50(6):781-789.

18. Parimon T, Au DH, Martin PJ, Chien JW. A risk score for mortality after allogeneic hematopoietic cell transplantation. Ann Intern Med. 2006;144(6):407-414.

19. Luznik L, O'Donnell PV, Fuchs EJ. Post-transplantation cyclophosphamide for tolerance induction in HLA-haploidentical bone marrow transplantation. Semin Oncol. 2012;39(6):683-693.

20. Bolaños-Meade J, Reshef R, Fraser R, Fei M, Abhyankar S, Al-Kadhimi $\mathrm{Z}$ et al. Three prophylaxis regimens (tacrolimus, mycophenolate mofetil, and cyclophosphamide; tacrolimus, methotrexate, and bortezomib; or tacrolimus, methotrexate, and maraviroc) versus tacrolimus and methotrexate for prevention of graft-versus-host disease with haemopoietic cell transplantation with reduced-intensity conditioning: a randomised phase 2 trial with a non-randomised contemporaneous control group (BMT CTN 1203). Lancet Haematol. 2019;6(3):e132-e143.
21. Bryant A, Mallick R, Huebsch L, Allan D, Atkins H, Anstee $\mathrm{G}$ et al. Low-Dose Antithymocyte Globulin for Graftversus-Host-Disease Prophylaxis in Matched Unrelated Allogeneic Hematopoietic Stem Cell Transplantation. Biol Blood Marrow Transplant. 2017;23(12):2096-2101.

22. Kennedy VE, Chen H, Savani BN, Greer J, Kassim AA, Engelhardt BG et al. Optimizing Antithymocyte Globulin Dosing for Unrelated Donor Allogeneic Hematopoietic Cell Transplantation Based on Recipient Absolute Lymphocyte Count. Biol Blood Marrow Transplant. 2018;24(1):150-155.

23. Alessandrino EP, Della Porta MG, Bacigalupo A, Malcovati L, Angelucci E, Van Lint MT et al. Prognostic impact of pre-transplantation transfusion history and secondary iron overload in patients with myelodysplastic syndrome undergoing allogeneic stem cell transplantation: a GITMO study. Haematologica. 2010;95(3):476-484. 


\section{Рандомизированное исследование тимоглобулина и пострансплантационного циклофосфана при алло- генной неродственной трансплантации у взрослых с хроническими миелоидными неоплазиями}

Елена В. Морозова, Иван С. Моисеев, Юлия Ю. Власова, Николай Ю. Цветков, Юлия В. Рудницкая, Мария В. Барабанщикова, Анна Г. Смирнова, Елена И. Дарская, Сергей Н. Бондаренко, Борис В. Афанасьев НИИ детской онкологии, гематологии и трансплантологии им. Р. М. Горбачевой, Первый Санкт-Петербургский государственный медицинский университет им. акад. И. П. Павлова, Санкт-Петербург, Россия

\section{Резюме}

В настоящий момент отмечается рост числа публикаций по поводу использования посттрансплантационного циклофосфана (ПТЦФ) в профилактике реакции «трансплантат против хозяина» при неродственной трансплантации гемопоэтических стволовых клеток. Тем не менее, большинство этих публикаций включают только пациентов с острыми лейкозами. Данные о возможности применения ПТЦФ при хроническом миелолейкозе (ХМЛ), миелодиспластическом синдроме (МДС) и хронических миелопролиферативных заболеваниях (ХМПЗ) практически отсутствуют, поэтому в данной популяции пациентов было инициировано проспективное рандомизированное сравнение тимоглобулина и ПТЦФ в профилактики РТПХ при 10/10- HLA совместимой неродственной трансплантации (NCT02627573, clinicaltrials.gov). Стратой для рандомизации был индекс pretransplant assessment of mortality. Исследование было прекращено преждевременно в связи с медленным набором пациентов, тем не менее, за время исследования было включено 33 пациента, 16 пациентов в группу тимоглобулина и 17 пациентов в группу ПТЦФ. Медиана наблюдения составила 29 месяцев. Не было выявлено различий ни в частоте первичного неприживления трансплантата $(12,50 \%$ против $11,8 \%, \mathrm{p}=0,9)$, ни острой
РТПХ II-IV степени (23\% vs 6\%, $\mathrm{p}=0,2)$, ни хронической РТПХ средней и тяжелой степени (25\% vs 23\%, $\mathrm{p}=0,4)$ в группах тимоглобулина и ПТЦФ, соответственно. Однако, было в группе ПТЦФ наблюдалась достоверно лучшая общая ( $82 \%$ vs $30 \%, \mathrm{p}=0,0126)$ и бессобытийная (61\% vs 26\%, $\mathrm{p}=0,0335)$ выживаемость, а также выживаемость без рецидива и РТПХ (61\% vs 16\%, p=0,0072). Различия были связаны с поздней инфекционной летальностью. Никак достоверных различий в токсичности 2 режимов выявлено не было. Подводя итоги, данное исследование дает обоснование для применения ПТЦФ при неродственных трансплантациях у пациентов с ХМЛ и МДС. Требуются дальнейшие исследования для подтверждения преимущества ПТЦФ над классической профилактикой с тимоглобулином.

\section{Ключевые слова}

Посттрансплантационный циклофосфан, миелодиспластический синдром, хронический миелоидный лейкоз, хроническая миелопролиферативная неоплазия, совместимый неродственный донор. 